\title{
Diagnosis and Management of Spinal Epidural Abscess
}

\author{
Gary J. Redekop, Rolando F. Del Maestro
}

\begin{abstract}
Twenty-five patients with spinal epidural abscess were treated at the University of Western Ontario hospitals between July 1980 and July 1990. There were eighteen males (72\%) and seven females (28\%), with a median age of 60 years. Concurrent illness resulting in immunocompromise was present in $60 \%$. Eleven presented with complete myelopathy, thirteen had limb weakness, and one had no neurological deficit. In twenty cases the abscess consisted of frankly purulent material, while in five the epidural collection consisted of chronic granulation tissue. Staphylococcus aureus was isolated in $64 \%$ of the abscesses. Twenty-seven surgical procedures were performed on 21 patients. Ten cases occurred in the cervical spine $(40 \%)$, seven in the thoracic spine (28\%), three in both the cervical and thoracic spine (12\%) and five in the lumbosacral spine $(20 \%)$. Fourteen patients $(56 \%)$ retained or recovered ambulation and there were five deaths $(20 \%)$. The progression from back and radicular pain to weakness and eventual paralysis continues to be characteristic of spinal epidural infection. Morbidity and mortality remain unacceptably high because of delay in diagnosis and treatment. Magnetic resonance imaging is the radiological investigation of choice for the diagnosis of spinal epidural abscess. Prompt intervention, before the development of severe neurological deficits, can improve outcome. Immediate surgical drainage combined with antibiotics remains the treatment of choice.
\end{abstract}

RÉSUMÉ: Diagnostic et traitement de l'abcès épidural spinal. Vingt-cinq patients avec abcès épidural spinal ont été traités dans des hôpitaux de l'Université de l'ouest de l'Ontario entre juillet 1980 et juillet 1990 . Vingt-huit étaient des hommes (72\%) et sept étaient des femmes (28\%), l'âge médian étant de 60 ans. Une maladie coexistante responsable d'un déficit immunitaire était présente chez $60 \%$ des cas. Onze présentaient une myélopathie complète, treize avaient de la faiblesse au niveau des membres et un n'avait pas de déficit neurologique. Chez vingt cas, le contenu de l'abcès était franchement purulent, alors que chez cinq la collection était composée de tissu de granulation chronique. Du staphylocoque doré a été isolé de $64 \%$ des abcès. On a procédé à vingt-sept interventions chirurgicales chez vingtet-un patients. Dix cas sont survenus au niveau du rachis cervical (40\%), sept au niveau du rachis dorsal (28\%), trois au niveau du rachis cervical et dorsal (12\%) et cinq au niveau du rachis lombosacré (20\%). Quatorze patients (56\%) ont conservé ou recouvré la marche et il y a eu cinq décès $(20 \%)$. La progression de la douleur dorsale et radiculaire à la faiblesse et à la paralysie éventuelle demeure caractéristique des infection épidurales spinales. La morbidité et la mortalité demeurent inacceptablement élevées à cause du retard à poser le diagnostic et à établir le traitement. L'imagerie par résonance magnétique est l'investigation radiologique de choix pour le diagnostic de l'abcès épidural spinal. Une intervention rapide, avant l'apparition de déficits neurologiques sévères, peut améliorer l'issue. Le draînage chirurgical immédiat combiné à l'antibiothérapie demeurent le traitement de choix.

Can. J. Neurol. Sci. 1992; 19: 180-187

Infection involving the spinal epidural space is a neurosurgical problem of considerable importance. Dandy' studied the anatomy of the epidural space and described the clinical features and management of pyogenic infections involving this region. Although effective surgical and antimicrobial therapy is available, delay in diagnosis and treatment continue to result in high morbidity and mortality. ${ }^{2-13}$

Twenty-five cases of spinal epidural abscess were treated at our institution between July 1980 and July 1990. The present study reviews their presentation and outcome, in order to emphasize the importance of early recognition of this disorder and to present current epidemiological and microbiological trends. A grading scheme based on clinical status at the time of presentation is proposed, and the impact of magnetic resonance imaging (MRI) on diagnosis is discussed.

\section{Material ANd Methods}

This study examines 25 cases of spinal epidural abscess treated by the Division of Neurosurgery at the University of

From the Brain Research Laboratories, Clinical Investigational Unit, Division of Neurosurgery, Department of Clinical Neurological Sciences, University of Western Ontario, London

Received August 14, 1991. Accepted in final form December 4, 1991

Reprint requests to: Dr. Gary Redekop, Division of Neurosurgery, Department of Clinical Neurological Sciences, The University of Western Ontario, London, Ontario, Canada N6A 5A5 
Western Ontario between July 1980 and July 1990. Information was obtained from hospital records, operative and pathological reports, and review of radiographs. All cases were verified at surgery or post-mortem examination.

Note was made of the first symptom experienced and the neurologic status at the time of presentation to the Division of Neurosurgery. A clinical grade was assigned to each patient based on the degree of neurologic dysfunction and systemic illness (Table 1). Grade I patients were those presenting with only back or radicular pain, without limb weakness. Grade 2 patients all had pain, but in addition had evidence of weakness in a radicular distribution or an incomplete myelopathy. Grade 3 patients presented with pain and complete myelopathy. Systemic sepsis, defined as the presence of fever, elevated white blood cell count and positive blood cultures, which was severe enough to result in hypotension or multi-organ failure, resulted in placement of the patient into the next least favorable category. Grade 4 patients were therefore those presenting with pain, complete myelopathy and systemic sepsis.

The results of radiologic investigations including plain radiographs, myelograms, computerized tomograms (CT) and MRI scans were compared with surgical and pathological findings. Culture and sensitivity results were tabulated in order to determine current trends and to provide guidelines for empiric therapy. The median follow-up was 24 months, with a minimum follow-up of 3 months (range 3 to 36 months).

\section{RESULTS}

Eighteen of the cases were male $(72 \%)$ and seven were female $(28 \%)$. The median age of patients was 60 years, with a range of 14 to 74 years. In 20 cases $(80 \%)$ the primary finding at the time of surgery or autopsy was frankly purulent material, while in 5 cases $(20 \%)$ epidural granulation tissue was found. Those patients whose epidural space contained frank pus had a median duration of symptoms prior to presentation of 11 days (range 4 days to 6 weeks), while those in which only epidural granulation tissue was found had a median duration of symptoms of 12 weeks (range 2 weeks to 6 months). Infections in which pus was identified were considered acute, while the presence of granulation tissue without pus was considered to represent a chronic infection. ${ }^{2}$

\section{Clinical Features}

Severe back pain was the initial symptom in all cases. A consistent pattern of clinical progression was found, characterized by back and radicular pain leading to weakness and eventual paralysis. At the time of presentation to the Division of Neurosurgery, one patient was classified as Grade $1(4 \%)$, nine

\begin{tabular}{ll}
\hline Table 1: & Clinical Grade of Spinal Epidural Abscess \\
\hline \hline Grade 1 & Back or radicular pain \\
Grade 2 & Weakness \\
Grade 3 & Paralysis \\
Grade 4 & Paralysis and systemic sepsis \\
\hline
\end{tabular}

Systemic sepsis, defined as the presence of an elevated WBC, fever, positive blood cultures and hypotension or multi-organ failure, results in placement into the next least favorable grade. as Grade $2(36 \%)$, nine as Grade $3(36 \%)$ and six as Grade 4 (24\%). Eleven patients $(44 \%)$ presented with complete myelopathy, six of which had systemic sepsis and by definition were Grade 4 patients.

In those patients with acute infection, the median temperature at presentation was $38.0^{\circ} \mathrm{C}$ (range 35.3 to $40.0^{\circ} \mathrm{C}$ ) and the median white blood cell count was $17.2 \times 10^{9} / \mathrm{L}$ (range 1.8 to $28.6 \times 10^{9} / \mathrm{L}$ ). Cases with chronic infection had a median tem. perature of $37.0^{\circ} \mathrm{C}$ (range 36.4 to $37.9^{\circ} \mathrm{C}$ ) and a median white cell count of $9.9 \times 10^{9} / \mathrm{L}$ (range 6.5 to $15.5 \times 10^{9} / \mathrm{L}$ ). Acute and chronic abscesses did not have any apparent difference in the percentage of patients presenting in each clinical grade, although there were only five chronic cases (Table 2).

\section{Source of Infection}

A source of infection was identified in 22 of the 25 patients (88\%) (Table 3). Cellulitis or cutaneous abscesses were present in five, respiratory infections in four and oropharyngeal infections in four. A history of previously diagnosed vertebral osteomyelitis was obtained in two cases. There was one postoperative wound infection and one case occurred following a cervical discogram.

\section{Predisposing Factors}

In 15 patients $(60 \%)$ there was a concurrent illness which was felt to significantly impair immunocompetence (Table 4). Five patients had diabetes mellitus and four had metastatic malignancy. There were no patients with AIDS or HIV seropositivity. Recent spine trauma was noted in three cases and a history of previous vertebral compression fracture at the involved spinal segment was found in three others.

\section{Radiographic Findings}

Plain radiographs were obtained in 24 of the 25 patients. One patient presented with overwhelming sepsis and died without any radiological investigation. These studies showed vertebral

\begin{tabular}{ccc}
\hline \multicolumn{3}{l}{ Table 2: Grade at Presentation in Acute and Chronic Cases } \\
\hline \hline Clinical Grade & Acute $(\mathbf{n}=\mathbf{2 0})$ & Chronic $(\mathbf{n}=\mathbf{5})$ \\
\hline \hline 1 & $1(5 \%)$ & $0(0 \%)$ \\
2 & $6(30 \%)$ & $3(60 \%)$ \\
3 & $8(40 \%)$ & $1(20 \%)$ \\
4 & $5(25 \%)$ & $1(20 \%)$ \\
\hline
\end{tabular}

Table 3: Source of Infection

\begin{tabular}{lcc}
\hline \hline Source & Number of Cases & Percent of Total \\
\hline Cellulitis/Cutaneous abscess & 5 & $20 \%$ \\
Pneumonia & 4 & $16 \%$ \\
Oropharyngeal abscess & 4 & $16 \%$ \\
Septic joint & 2 & $8 \%$ \\
Vertebral osteomyelitis & 2 & $8 \%$ \\
Gastrointestinal tract & 2 & $8 \%$ \\
Wound infection & 1 & $4 \%$ \\
Psoas abscess & 1 & $4 \%$ \\
Cervical discogram & 1 & $4 \%$ \\
No source identified & 3 & $12 \%$ \\
\hline
\end{tabular}


body destruction in 5 cases (20\%) and disc space erosion in 3 cases (15\%). Purulent discitis in addition to epidural abscess was found in 7 cases; thus, plain radiographs were predictive of purulent disc space infection in 3 of 7 cases (43\%). Bone was not examined pathologically in all cases; therefore the incidence of concurrent vertebral osteomyelitis could not be determined.

Myelography was performed in 19 cases. Complete block suggestive of epidural compression was seen in $14(74 \%)$ and incomplete block seen in $5(26 \%)$. Of those with complete block, satisfactory visualization above and below the lesion was provided in only one $(7 \%)$. Five patients with complete block $(36 \%)$ required multiple surgical procedures due to inadequate demonstration of the extent of the compression by the myelogram. Two patients who initially underwent anterior cervical decompression subsequently required posterior laminectomy. Three patients had initial procedures which were insufficient in their rostocaudal extent and were subjected to a second myelogram and further surgical decompression. One patient required three surgical procedures.

CT scans were obtained in 10 cases, usually following myelography. Although epidural compressive lesions were easily appreciated, the upper and lower extent could be reliably determined in only 4 patients (40\%).

Six patients underwent MRI examination, consisting of T1 and $T 2$ weighted images obtained in sagittal planes and $\mathrm{T} 1$ weighted images obtained in axial planes. Disc space and soft tissue infection was associated with increased signal intensity on T2 weighted images (TR $2500 \mathrm{~ms}$, TE $70 \mathrm{~ms}$ ), with spinal cord displacement and compression seen best on Tl weighted images (TR $600 \mathrm{~ms}$, TE $20 \mathrm{~ms}$ ) (Figure 1). Vertebral osteomyelitis was recognized by reduced signal intensity on $\mathrm{Tl}$ weighted images and increased signal intensity on T2 weighted images (Figure 2). ${ }^{14-16}$ In all six cases there was excellent demonstration of the bone and soft tissue infection. Post-operative images confirmed the satisfactory decompression of the epidural space (Figure 3).

\section{Surgical Procedures}

Twenty-seven surgical procedures were performed on 21 patients. In four cases, only post-mortem information was available. Epidural abscess tissue was found posteriorly in 20 cases and anteriorly in 8 cases. Three patients had both anterior and posterior abscess extension. The cervical spine was involved in 10 cases $(40 \%)$, thoracic spine in $7(28 \%)$ and lumbosacral spine in $5(20 \%)$. Three cases $(12 \%)$ involved both the cervical and thoracic spine. The rostrocaudal extent of surgical decompression ranged from 2 to 15 vertebral levels (median $=5$ levels).

Table 4: Factors Predisposing to Infection

\begin{tabular}{lcc}
\hline \hline Predisposing Factor & Number of Cases & Percent of Total \\
\hline Diabetes mellitus & 5 & $20 \%$ \\
Malignancy & 4 & $16 \%$ \\
Alcohol or drug abuse & 3 & $12 \%$ \\
Chronic steroid use & 1 & $4 \%$ \\
Malaria & 1 & $4 \%$ \\
Ulcerative colitis & 1 & $4 \%$ \\
Recent trauma & 3 & $12 \%$ \\
Previous compression fracture & 3 & $12 \%$ \\
No predisposing factors & 10 & $40 \%$ \\
\hline
\end{tabular}

\section{Microbiology}

Positive cultures were obtained in 24 cases $(96 \%)$. Staphylococcus aureus was the sole infectious agent in 16 individuals (64\%), and in each case was sensitive to cloxacillin (Table 5). Streptococcus pyogenes was cultured in 3 cases $(12 \%)$; multiple organisms were found in two patients $(8 \%)$.

\section{Outcome}

Outcome was classified as excellent, good, poor or death (Table 6). Fourteen patients retained or recovered ambulation. There were 4 excellent results (16\%), 10 good $(40 \%), 6$ poor (24\%) and 5 deaths (20\%). Long-term outcome results were calculated for each clinical grade at presentation (Table 7). There was clearly a trend to better results in those who presented in a lower clinical grade. All five patients who died had systemic sepsis at the time of presentation. This represents a mortality rate of $42 \%$ among the 12 patients presenting with sepsis. Neither age nor sex affected outcome for a particular grade. There were no differences in the proportion of good or excellent results obtained in those with acute and chronic abscesses. However, all five deaths occurred in the acute group (Table 8).

\section{Discussion}

The incidence of spinal epidural abscess remains approximately 1 to 2 per 10,000 hospital admissions. ${ }^{2,6.7}$ In the present series, two cases $(8 \%)$ occurred in patients less than 20 years of age, consistent with the low reported incidence of this illness in the pediatric population. ${ }^{17}$ We classified the cases as acute or chronic based on the duration of symptoms and the pathological findings of pus or granulation tissue, as has been described previously. ${ }^{2.4-6.89 .11 .12 .18}$ Although the chronic abscesses presented with a lower temperature and white blood cell count, there was

Table 5: Microbiology

\begin{tabular}{lcc}
\hline \hline Infectious Agent & Number of Cases & Percent of Total \\
\hline Staphylococcus aureus & 16 & $64 \%$ \\
Streptococcus pyogenes & 3 & $12 \%$ \\
Escherichia coli & 1 & $4 \%$ \\
Bacteroides melaninogenicus & 2 & $8 \%$ \\
Multiple organisms: & 2 & $8 \%$ \\
$\quad$ Eikenella corrodens, & & \\
$\quad$ Bacteroides melaninogenicus. & & \\
Streptococcus viridans & \\
$\quad$ Staphylococcus aureus, & & \\
$\quad$ Fusobacterium, & \\
$\quad$ Peptostreptococcus & & \\
No organism cultured & 1 & \\
\hline
\end{tabular}

Table 6: Outcome

\begin{tabular}{lccc}
\hline \hline Result & Criteria & $\begin{array}{c}\text { Number } \\
\text { of Cases }\end{array}$ & $\begin{array}{c}\text { Percent } \\
\text { of Total }\end{array}$ \\
\hline Excellent & $\begin{array}{c}\text { No residual deficit } \\
\text { Ambulatory but with } \\
\text { residual weakness or } \\
\text { neurogenic bladder }\end{array}$ & 4 & $16 \%$ \\
Poor & Non-ambulatory & 6 & \\
Death & & 5 & $24 \%$ \\
\hline
\end{tabular}


no difference between acute and chronic cases in terms of clinical grade at presentation or functional recovery. Curling et al. ${ }^{3}$ and Hlavin et al. ${ }^{7}$ have reported similar observations, suggesting that the distinction between acute and chronic cases is arbitrary and not of clinical importance. Heusner ${ }^{6}$ felt that the chronicity of infection does not reliably predict whether pus or granulation tissue will be found. In this series, there was a shorter median duration of symptoms prior to presentation in the group with frankly purulent abscesses, but the number of cases was too small for meaningful statistical analysis.

Infection reaches the epidural space by direct extension from an established infection or by a hematogeneous route. Although vertebral osteomyelitis is the most common source of contiguous infection, ${ }^{19-24}$ retropharyngeal, psoas, pulmonary and perinephric abscesses have also been implicated. ${ }^{25}$ Epidural abscess has been reported as a complication of gastrointestinal surgery, ${ }^{26}$ epidural anesthesia, ${ }^{27}$ local anesthetic injection, ${ }^{28}$ chemonucleolysis, ${ }^{29}$ and serial lumbar punctures. ${ }^{30}$ One of our cases, with epidural and subdural empyema, has previously been reported as a complication of cervical discography. ${ }^{31}$ Hematogenous

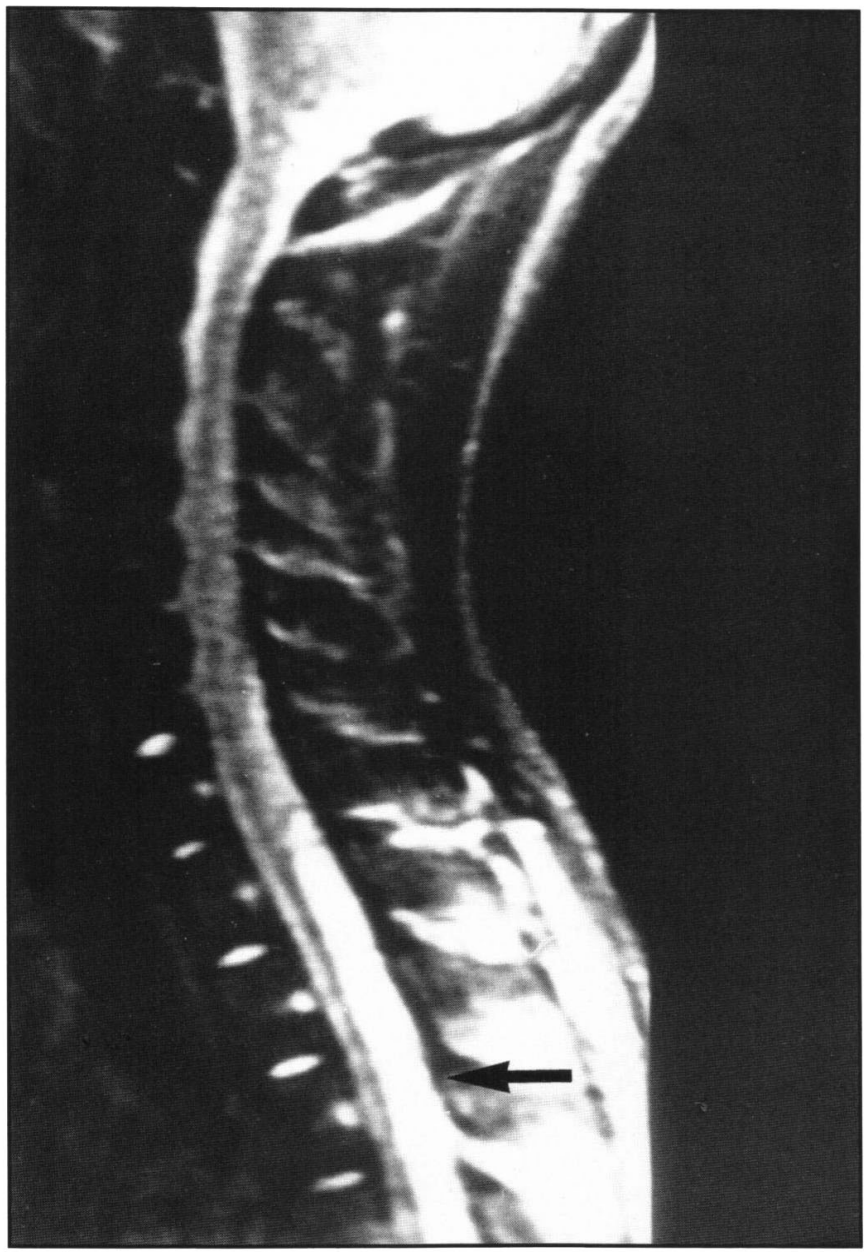

A spread has most commonly resulted from cutaneous infections, pneumonia, dental abscesses and urinary tract infections. ${ }^{24}$ In



B

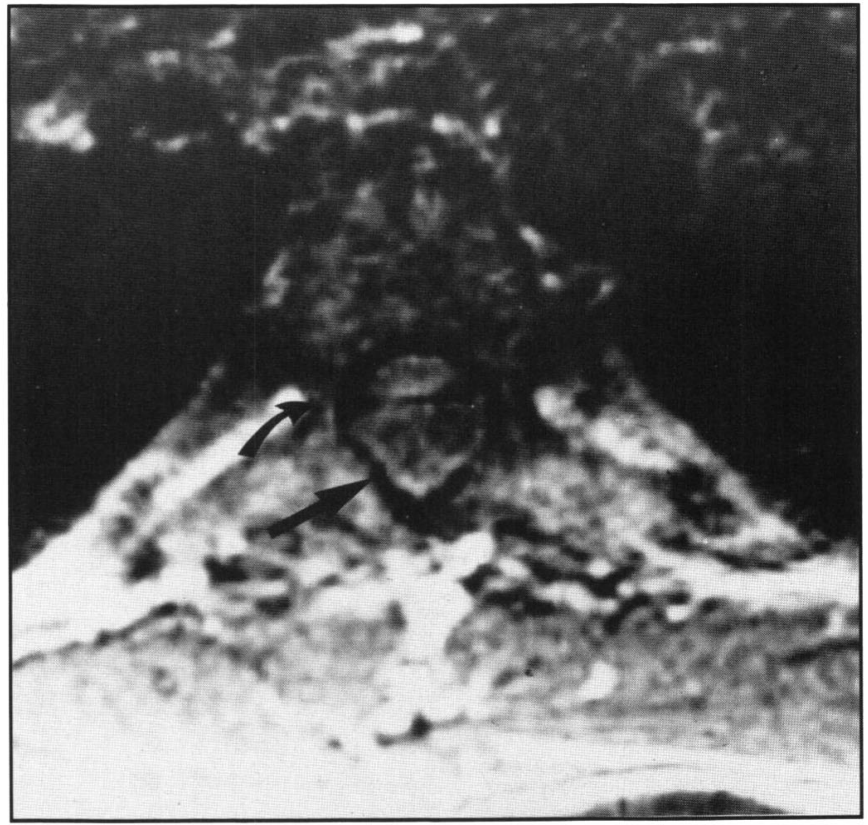

C

Figure I - MRI scans of a 2 I-year-old male with a posterior spinal epidural abscess from C6 to TIO. (A) Sagittal T2 weighted image (TR 2500 ms, TE $70 \mathrm{~ms}$ ) of the cervical and upper thoracic spine demonstrating a focal area of high signal intensity in the posterior epidural space (arrow). resulting in displacement and compression of the spinal cord. (B) Sagittal T2 weighted image of the lower thoracic spine, showing the posterior epidural mass (arrow). (C) Axial Tl weighted image (TR $600 \mathrm{~ms}$. TE $20 \mathrm{~ms}$ ) of the thoracic spine demonstrating a multi-loculated posterior epidural mass (straight arrow), compressing the spinal cord anteriorly (curved arrow'). 


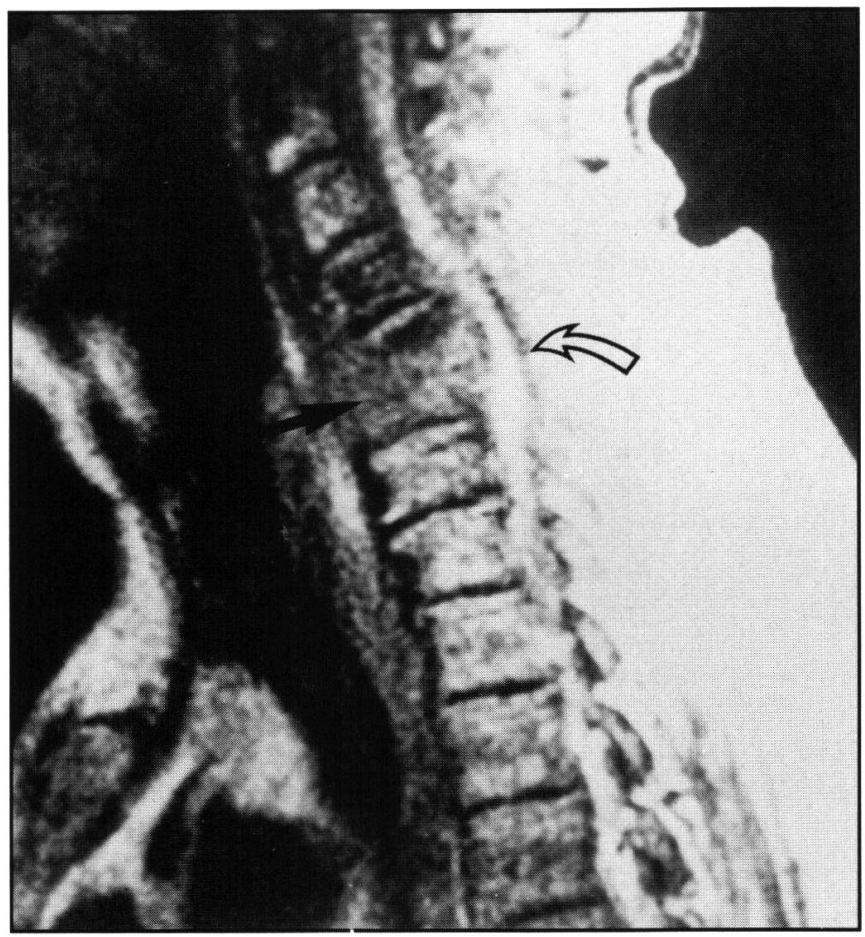

A

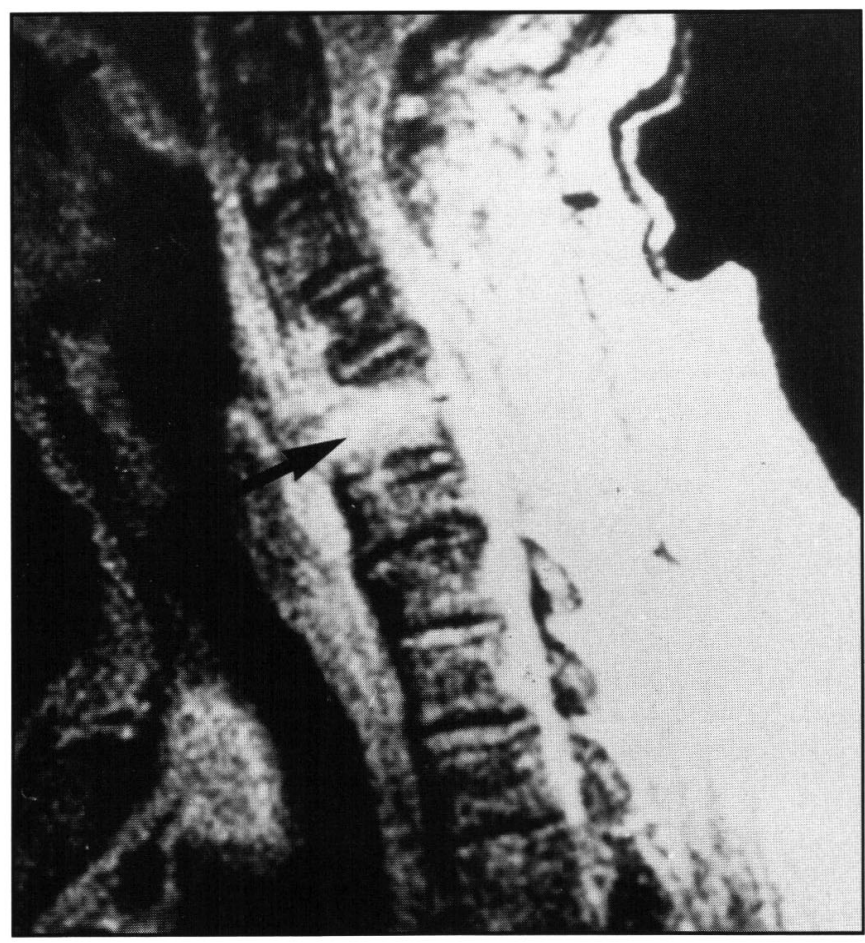

B

Figure 2 - Sagittal MRI scans of a 68-year-old male with vertebral osteomyelitis of $C 5$ and C6, associated with an anterior epidural abscess. (A) TI weighted image (TR $600 \mathrm{~ms}$, TE $20 \mathrm{~ms}$ ) showing reduced signal intensity and collapse of C5 and C6 (solid arrow), with an anterior epidural mass compressing the spinal cord posteriorly (open, curved arrow). (B) T2 weighted image (TR $2000 \mathrm{~ms}, T E 30 \mathrm{~ms}$ ) showing increased signal from the vertebral bodies of $C 5$ and $C 6$ (arrow). This pattern of signal change is consistent with vertebral osteomyelitis.

\begin{tabular}{|c|c|c|c|c|}
\hline \multirow{2}{*}{$\begin{array}{l}\begin{array}{l}\text { Clinical } \\
\text { Grade }\end{array} \\
1\end{array}$} & \multirow{2}{*}{$\begin{array}{c}\begin{array}{c}\text { Number } \\
\text { of Cases }\end{array} \\
1\end{array}$} & \multicolumn{2}{|c|}{ Outcome } & \multirow{2}{*}{$\begin{array}{c}\begin{array}{c}\text { Percent } \\
\text { Ambulatory }\end{array} \\
100 \%\end{array}$} \\
\hline & & $\begin{array}{l}\text { Excellent } \\
\text { Good } \\
\text { Poor } \\
\text { Death }\end{array}$ & $100 \%$ & \\
\hline 2 & 9 & $\begin{array}{l}\text { Excellent } \\
\text { Good } \\
\text { Poor } \\
\text { Death }\end{array}$ & $\begin{array}{l}22 \% \\
56 \% \\
11 \% \\
11 \%\end{array}$ & $78 \%$ \\
\hline 3 & 9 & $\begin{array}{l}\text { Excellent } \\
\text { Good } \\
\text { Poor } \\
\text { Death }\end{array}$ & $\begin{array}{l}11 \% \\
45 \% \\
11 \% \\
33 \%\end{array}$ & $56 \%$ \\
\hline 4 & 6 & $\begin{array}{l}\text { Excellent } \\
\text { Good } \\
\text { Poor } \\
\text { Death }\end{array}$ & $\begin{array}{r}0 \% \\
17 \% \\
66 \% \\
17 \%\end{array}$ & $17 \%$ \\
\hline
\end{tabular}

Table 8: Outcome in Acute and Chronic Cases

\begin{tabular}{lcc}
\hline \hline Outcome & Acute $(\mathbf{n}=\mathbf{2 0})$ & Chronic $(\mathbf{n}=\mathbf{5})$ \\
\hline Excellent & $2(10 \%)$ & $2(40 \%)$ \\
Good & $9(45 \%)$ & $1(20 \%)$ \\
Poor & $4(20 \%)$ & $2(40 \%)$ \\
Death & $5(25 \%)$ & $0(0 \%)$ \\
\hline
\end{tabular}

the cases reported in the present series, hematogenous spread may have accounted for up to $80 \%$ of infections (Table 3 ). Antecedent trauma has been suggested as a predisposing factor by creating a "locus minoris resistentiae". ${ }^{20.21}$

All reported series have emphasized the importance of Staphylococcus aureus as an etiologic agent in this infection. ${ }^{2,4-6.8-13.20,21}$ However, recent series ${ }^{3.7}$ have shown that the spectrum of organisms is becoming more diverse, with gram negative infections assuming a prominent role. ${ }^{3.9}$ In this series, $S$. aureus alone was isolated in 16 patients $(64 \%)$ and $S$. pyogenes in $3(12 \%)$, while gram negative, anaerobic and mixed infections were found in $5(20 \%)$.

Spinal epidural abscess continues to be an affliction of the elderly and those with compromised immune status. Diabetes, malignancy, chronic renal failure, alcoholism and IV drug abuse have been identified as significant risk factors. ${ }^{4.7 .9}$ The median age of our patients was 60 years, and in $60 \%$ there was a predisposition to infection due to chronic illness or substance abuse. Similar observations have been presented in other large series..$^{3.4 .7}$

In most previously reported series, the most common location for epidural abscess has been the thoracic or lumbar area. The cervical spine has been the rarest site of involvement ${ }^{23.32}$ presumably because the epidural space is merely potential at the cervical level, becoming more substantial caudally. ${ }^{1}$ This series is the first to report an increased incidence in the cervical region (52\%).

There has been debate in the literature as to the relative importance of vascular thrombosis and mechanical cord compression in the pathogenesis of neurological deficits resulting 
from spinal epidural abscess. ${ }^{2.20 .21 .33}$ In autopsied patients, Russell et al. ${ }^{12}$ observed no arterial compromise but did find venous compression and thrombosis, thrombophlebitis of the epidural space, venous infarction and edema. Feldenzer et al., ${ }^{34,35}$ using a rabbit model, have demonstrated that a mechanical, compressive effect is the early cause of neurological impairment, with progressive ischemia and thrombosis in addition to compression adding to the severity and permanence of the lesion. Recognition of the importance of mechanical compression as the initial pathological factor suggests that, in extensive abscesses, the thoracic spine with its limited space may be the earliest and most severely affected level.

We have classified patients into four categories based on their clinical presentation and degree of neurological dysfunction (Table 1). Clearly, those with the least neurological deficit at the time of diagnosis and treatment have the best chance for recovery (Table 7). In addition to the severity of pre-existing deficits, the duration of symptoms prior to surgery has been shown to be a significant predictive factor by Baker et al. ${ }^{2}$ and Danner and Hartman. ${ }^{4}$ In their series, Danner and Hartman ${ }^{4}$ found that only two of eleven patients with weakness or paralysis for greater than 36 hours improved, while all seven patients with neurologic impairment for less than 36 hours had some recovery following surgery. In the present series, of five Grade 3 patients who had complete myelopathy without systemic sepsis,

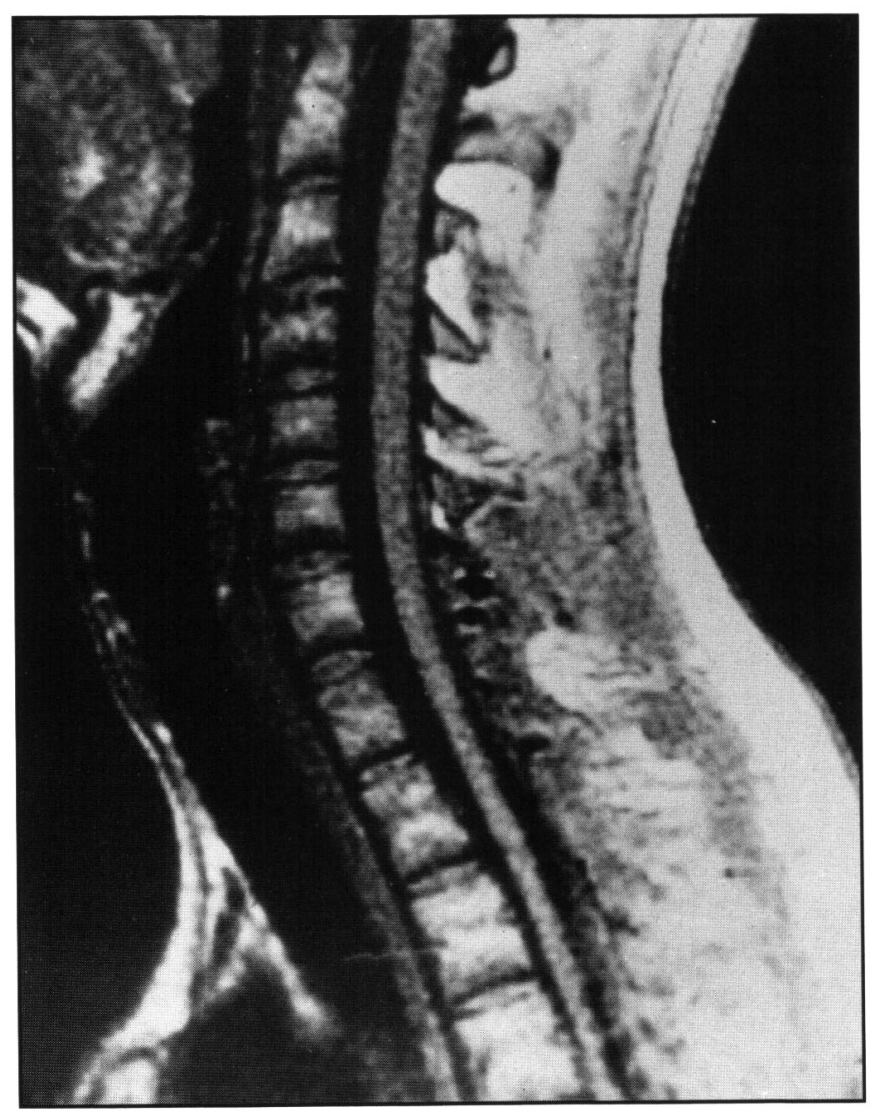

A

Figure 3 - Post-operative TI weighted MRI scans (TR $600 \mathrm{~ms}, T E 20 \mathrm{~ms}$ ) of the same patient as in Figure I. (A) Sagittal image of the cervical and upper thoracic spine. (B) Sagittal image of the lower thoracic spine. (C) Axial image of the lower thoracic spine, showing satisfactory decompression following laminectomy (arrow). Compare to Figure $/(C)$.

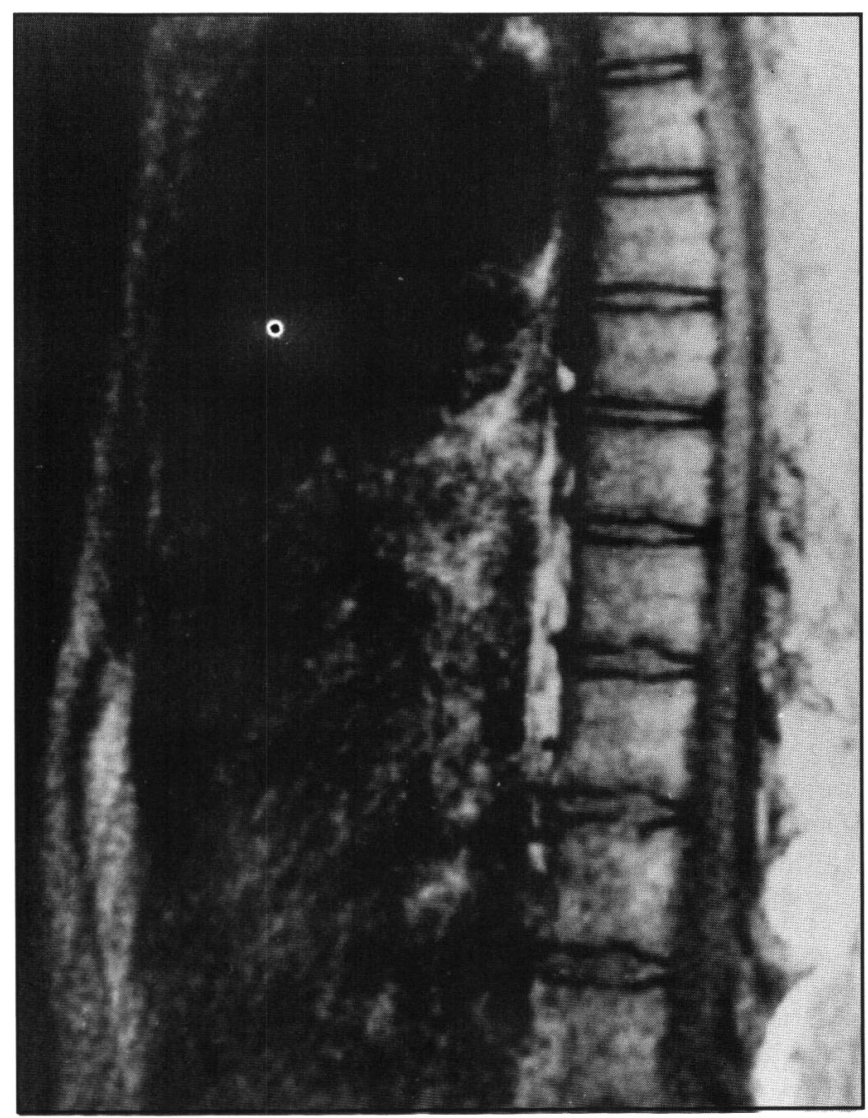

$\mathbf{B}$

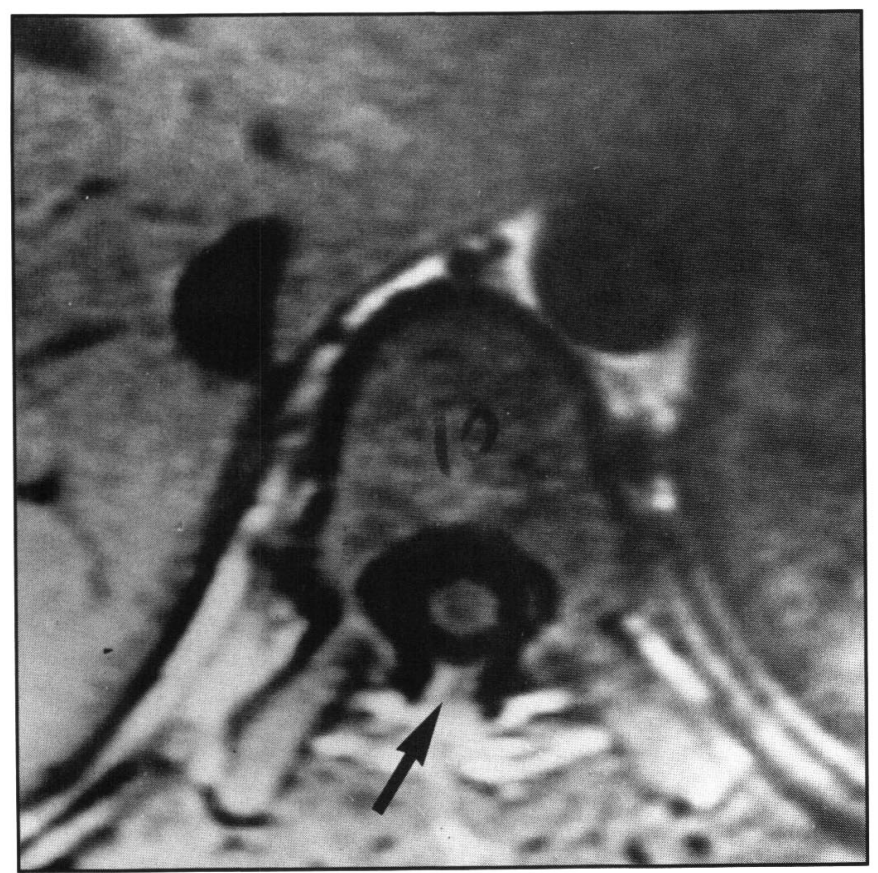

C 
four recovered ambulation, while only one of six Grade 4 patients improved to this level. Generalized sepsis thus appears to significantly reduce the probability of functional recovery, but even patients with complete myelopathy can improve following appropriate management. These results emphasize the importance of early recognition and prompt treatment of patients with this illness.

Before the advent of computerized imaging, the recommended investigation of patients with back pain, fever and spine tenderness included radiographs of the spine, lumbar puncture and myelography. ${ }^{2.49} .10 .13$ Emphasis was placed on finding an elevated CSF protein concentration together with a pleocytosis, as well as myelographic evidence of epidural compression. However, this diagnostic strategy exposed patients to the risks associated with lumbar puncture, including purulent meningitis, while obtaining only limited information in the majority of cases. In this series, only one of fourteen (7\%) myelographic studies demonstrating a complete block adequately confirmed the upper and lower extent of the abscess. By definition, a complete myelogram in this setting requires puncture both above and below the block, further increasing the risks. Magnetic resonance imaging has become increasingly available as a non-invasive means to accurately identify the nature and extent of spinal pathology, and compares favorably with plain radiography, myelography and $\mathrm{CT}$ scanning. ${ }^{14-16.36-38} \mathrm{~A}$ prospective study has demonstrated the superiority of MRI to conventional and CT myelography in the evaluation of cervical myelopathy. ${ }^{37}$ Our results in six patients evaluated with MRI have been superior to all other modalities in demonstrating the rostrocaudal extent and anteroposterior spread of infection, as well as bone, disc and paraspinal involvement.

Although there have been isolated case reports ${ }^{39,40}$ and small series $^{41.42}$ of spinal epidural abscess managed conservatively, the fundamental surgical principle of drainage of pus has not been diminished by the early use of antibiotics. This premise is supported by the demonstration of the importance of mechanical compression in causing the early neurological deficit associated with spinal epidural abscess. ${ }^{34.35}$ In the series of Hlavin et al., ${ }^{7}$ eleven patients with initially normal neurological examinations deteriorated in the hospital before surgical intervention. Eight of those patients were being treated with appropriate antibiotics. Two became paralyzed despite more than three weeks of antibiotic therapy, and only three of the eleven recovered fully. They observed that patients who are initially neurologically normal and who then deteriorate while receiving antibiotic therapy have a significantly worse prognosis after operation than those operated upon while neurologically intact. Aggressive surgical management remains the key to successful treatment, with nonoperative therapy limited to a select group with high operative risk, no evidence of neural compression and in whom positive cultures have been obtained.

Appropriate treatment includes the immediate institution of empiric intravenous antibiotics as soon as blood cultures have been drawn. Because of the changing microbiology of this disease, broad spectrum antimicrobial coverage, including an antistaphylococcal penicillin, is recommended as the initial therapeutic regimen, until the results of culture and sensitivity testing are known. Intravenous medication should be continued for at least two weeks, with oral agents administered for another four weeks. ${ }^{3.24}$ Prolonged administration, for up to 8 weeks, has been suggested for those patients with concurrent vertebral osteomyelitis. 2.3 .24

\section{Conclusions}

The progression from back and radicular pain to weakness and eventual paralysis remains characteristic of spinal epidural abscess. The distinction between acute and chronic forms of this illness does not appear to have clinical significance. We have noted an increased frequency of occurrence in the cervical spine, and found MRI to be the imaging modality of choice. A therapeutic protocol of early operative drainage and appropriate antibiotics seems to be justified by our experience and that of others. ${ }^{3.7}$ Early diagnosis is vital to the improvement of overall patient outcome, since the presence of systemic sepsis or severe neurological deficit is associated with a poor chance of functional recovery. Improvement in therapeutic results is dependent on a high index of suspicion, early diagnosis, and prompt intervention with surgical drainage and antibiotics.

\section{ACKNOWLEDGEMEN'}

Dr. Del Maestro is the recipient of an Ontario Ministry of Health Career Scientist Award.

\section{REFERENCES}

1. Dandy WE. Abscesses and inflammatory tumours in the spinal epidural space (so-called pachymeningitis externa). Arch Surg 1926; 13: 477-494.

2. Baker AS, Ojemann RG, Swartz MN, et al. Spinal epidural abscess. N Engl J Med 1975; 293: 463-468.

3. Curling OD, Gower DJ, McWhorter JM. Changing concepts in spinal epidural abscess: a report of 29 cases. Neurosurgery 1990; 27: 185-192.

4. Danner RL, Hartman BJ. Update of spinal epidural abscess: 35 cases and review of the literature. Rev Infect Dis 1987; 9: 265 274.

5. Hancock DO. A study of 49 patients with acute spinal extradural abscess. Paraplegia 1973; 10: 285-288.

6. Heusner AP. Nontuberculous spinal epidural infections. N Engl J Med 1948; 239: 845-854.

7. Hlavin ML, Kaminski HJ, Ross JS, et al. Spinal epidural abscess: a ten year perspective. Neurosurgery 1990;27: 177-184

8. Hulme A, Dott NM. Spinal epidural abscess. Br Med J 1954; 1 : 64-68.

9. Kaufman DM, Kaplan JG, Litman N. Infectious agents in spinal epidural abscess. Neurology 1980; 30: 844-850.

10. Phillips GE, Jefferson A. Acute spinal epidural abscess. Observations from fourteen cases. Postgrad Med J 1979; 55: 712-715.

11. Ravicovitch MA, Spallone A. Spinal epidural abscesses: surgical and parasurgical management. Eur Neurol 1982; 21: 347-357.

12. Russell NA, Vaughan R, Morley TP. Spinal epidural infection. Can J Neurol Sci 1979; 6: 325-328.

13. Yang SY. Spinal epidural abscess. NZ Med J 1982; 95: 302-304.

14. Aichner F, Poewe W, Rogalski W, et al. Magnetic resonance imaging in the diagnosis of spinal cord disease. J Neurol Neurosurg Psychiatry 1985; 48: 1220-1229.

15. Larsson EM, Holtas S, Conqvist $S$. Emergency magnetic resonance examination of patients with spinal cord symptoms. Acta Radiol 1988; 29: 69-75.

16. Modic MT, Feiglin DH, Pirains DW, et al. Vertebral osteomyelitis: assessment using MR. Radiology 1985; 157: 157-166.

17. Fischer EG, Green CS, Winston KR. Spinal epidural abscess in children. Neurosurgery 1981;12:859-867.

18. Dus V. Spinal pachymeningitis (epidural abscess). Report of eight cases. J Neurosurg 1960; 28: 972-983.

19. Abramovitz JN, Batson RA, Yablon JS. Vertebral osteomyelitis. The surgical management of neurological complications. Spine 1986; 11: 418-420. 
20. Browder J, Meyers R. Infections of the spinal epidural space: an aspect of vertebral osteomyelitis. Am J Surg 1937; 37: 4-26.

21. Browder J, Meyers R. Pyogenic infections of the epidural space. Surgery 1941; 10: 296-308.

22. LaRocca H. Infections of the spine. Clin Neurosurg 1979; 26: 296304.

23. Lasker BR, Harter DH. Cervical epidural abscess. Neurology 1987; 37: 1747-1753.

24. Verner EF, Musher DM. Spinal epidural abscess. Med Clin N Am 1985; 69: 375-384.

25. Koopman CF, Miller RW, Coulthard SW. Retropharyngeal abscess associated with progressive quadriplegia, an epidural abscess, renal failure and jaundice. Case report. Otolarygol Head Neck Surg 1984; 92: 114-118.

26. Walters DA, Moussa SA, Buyukpomuku N. Epidural abscess complicating Swenson procedure: a case report and review of the literature. J Ped Surg 1984; 19: 218-220.

27. Wanscher M, Rhshede L, Krogh B. Fistula formation following epidural catheter. Case report. Acta Anaesthesiol Scand 1985; 29: 552-553.

28. Rustin MH, Coones EN, Flynn MD. Acute sacral epidural abscess following local anesthetic injection. Postgrad Med J 1983; 59: 399-400.

29. Brian JE, Westerman GR, Chadduck WM. Septic complications of chemonucleolysis. Neurosurgery 1984; 15: 730-734.

30. Bergman I, Wald E, Mayer J, et al. Epidural abscess and vertebral osteomyelitis following serial lumbar punctures. Pediatrics 1983; 72: 476-480

31. Lownie S, Ferguson G. Spinal subdural empyema complicating cervical discography. Spine 1989; 14: 1415-1417.
32. Durity F, Thompson GB. Localized cervical epidural abscess. Case report. J Neurosurg 1968; 28: 387-390.

33. Syrjanen $M$, Hvahainen $M$, Kallio $M$, et al. Three different pathogenic mechanisms for paraparesis in association with bacterial infections. Ann Clin Res 1986; 18: 191-194.

34. Feldenzer JA, McKeever PE, Schaberg DR, et al. Experimental spinal epidural abscess: a pathophysiological model in the rabbit. Neurosurgery 1987; 9: 859-867.

35. Feldenzer JA, McKeever PE, Schaberg DR, et al. The pathogenesis of spinal epidural abscess: microangiopathic studies in an experimental model. J Neurosurg 1988; 69: 110-114.

36. Burke DR, Brant-Zawadski M. CT of pyogenic spine infection. Neuroradiology 1985; 27: 131-137.

37. Masaryk TJ, Modic MT, Geisinger MA, et al. Cervical myelopathy: a comparison of magnetic resonance and myelography. $J$ Comput Assist Tomogr 1986; 10: 184-194.

38. Schmutzhard E, Aichner F, Dierckz R, et al. New perspectives in acute spinal epidural abscess illustrated by two case reports. Acta Neurochir 1986; 80: 105-108.

39. Bouchez B, Arnott G, Delfosse J. Acute spinal epidural abscess. J Neurol 1985; 231: 343-344.

40. Messer HD, Lenchner GS, Brust JC, et al. Lumbar spinal abscess managed conservatively. J Neurosurg 1977; 46: 825-829.

41. Leys D, Lesoin F, Viaud C, et al. Decreased morbidity from acute bacterial spinal epidural abscess using computed tomography and nonsurgical management in selected patients. Ann Neurol 1985; 17: 350-355.

42. Mampalam TJ, Rosegay H, Andrew BT, et al. Nonoperative treatment of spinal epidural infections. J Neurosurg 1989; 71: 208210 . 